\title{
RESEARCH ON THE PRICES OF FLATS IN THE SOUTH EAST LONDON AND VILNIUS
}

\author{
Saulius RASLANAS ${ }^{1}$, Laura TUPĖNAITE் ${ }^{2}$ and Tadas ŠTEINBERGAS ${ }^{3}$ \\ 1 Department of Construction Economics and Property Management, \\ Vilnius Gediminas Technical University, Sauletekio al. 11, LT-10223 Vilnius, Lithuania. \\ E-mail: Saulius.Raslanas@st.vtu.lt \\ 2 Strategic Analysis Unit, Vilnius Gediminas Technical University, Sauletekio al. 11, \\ LT-10223 Vilnius, Lithuania. E-mail: Laura.Tupenaite@adm.vtu.lt \\ 3 Barnfield Construction Ltd, 8 Kenyon Rd, Nelson, BB9 5SP, U.K.
}

Received 11 May 2005; accepted 23 September 2005

\begin{abstract}
Mathematical statistics methods were applied to analyse the pricing of two bedroom flats in South-eastern London and similar sized three room flats in Vilnius. Analysis revealed that the average prices of Vilnius three room flats are 4-5 times less comparing to prices of two bedroom flats in South-eastern London. Also flat prices influencing factors such as living space, dwelling condition, communication, parking space, additional space, storey, etc. were compared. It was found that some additional factors are influencing dwelling prices in Vilnius rather as in London. More attention must be paid on multi-storey buildings age and construction type. These factors are important in Vilnius living areas where panel buildings are common - Antakalnis, Fabijoniškès, Pašilaičiai, Šeškinè, etc. Other pricing influencing factors are similar to London, most often the condition of the flat is the most important factor to Vilnius three rooms dwelling pricing. As Vilnius is much smaller than London, communication and parking area do not have much influence on dwelling prices. Similar to London, the space of dwelling is more important factor in Vilnius living areas than in central parts of the city and prestigious districts.
\end{abstract}

KEYWORDS: Correlative-regressive analysis; Significant factors; Prices for one square metre in residential areas

\section{INTRODUCTION}

London is a huge metropolitan city, one of the main world centres of trade, finance and culture, a capital of an economically strong country and the centre of the former largest world empire. London is characterised by the expensive living and one of the highest dwelling prices in the EU.

Vilnius is the capital of the country which is among the most competitive capitals in the transition period. Vilnius is characterised by an exceptionally rapid growth of dwelling prices, life quality improvement and rapid eco- nomic, social and cultural progress in recent years.

Although prices of flats have been constantly growing in Vilnius in recent years, it must be admitted that they are considerably lower than in London. Such tendencies are determined not only by different economic development level in Lithuania and in Great Britain but also by many other factors which must be considered while determining prices of flats and forecasting their values. For this purpose various mathematical-statistical methods may be used. For example, scientists of Glamorgan University (Great Britain) Wilson, Paris etc. 
offer to use neural networks to forecast prices of flats [18], US scientists Sieg, Smith, etc. recommend to use regressive modelling based on transformation of non-homogeneous data on prices of flats to homogeneous for the evaluation of the factors which determine the value of a dwelling as well as determination of the real value of a dwelling [16].

Mathematical statistics methods may be also used for the comparison of prices of flats and the determining factors in different countries. In this case, flats with two bedrooms located in the South East London area and analogical (according to the total area) three-room flats in Vilnius were selected for the research; their prices were determined using statistical methods, and the factors determining prices of flats were identified and compared using correlative-regressive analysis.

\section{PRICES OF TWO-BEDROOM FLATS IN THE SOUTH EAST LONDON AND THE DETERMINING FACTORS}

London is among the most densely populated territories both in England and the UK. The areas that belong to London are divided to internal and external; the latter were attached to the city only within the last two centuries. The data of 2003 shows that there were $3,109,657$ dwellings suitable for living in the city, and construction and renovation works continue. Besides, city development projects are being implemented in an attempt to host the Olympic Games in 2012 in London and it was successful.

About one half of all dwellings in London are flats; London areas located in the South East are not an exception, and more spacious two-bedroom flats are popular there. Their prices and determining qualitative and quantitative factors are analysed below.

The following areas belong to the South East part of London: Bexley, Bromley, Croydon, Greenwich, Lambeth, Lewisham and Southwark [11].

External areas (Bromley, Bexley and
Croydon) are less densely populated and are dominated by semi-detached or sometimes low detached houses, and the supply of flats most often consists of premises in these houses of various layouts.

The areas located near the centre (Lambeth and especially Southwark) are dominated by dwelling houses of five and more storeys.

Greenwich and Lewisham areas are dominated by semi-detached houses, a number of multi-storey buildings among them (their number increases approaching the centre). Types of flats are diversified compared to the newly constructed areas of Depford and Woolwich and other areas located at the river where a large scale project Thames Gateway is being implemented. The project includes construction of new dwellings, improvement of infrastructure, transport system and education system.

The area of Greenwich is attractive to construction companies, because there still are a number of abandoned former docks alongside of the river (the northern part of the Greenwich area and the southern parts of Newham and Barking\&Dagenham areas are often simply titled Docklands), and prestigious multistorey buildings are being constructed in their territories. Besides, the areas are crowded by tourists and also have many and beautiful parks. On the other hand, Lewisham is more a residential area but its separate parts still retain many advantages of Greenwich.

Since London is large, its division to areas is conditional; therefore, the dwelling place is usually defined not by the name of the area but by a post code (to be precise, its initial part). Therefore, this classification, which enables the collection of more homogeneous data, was used in the analysis of the territories.

The areas of South East London for which we succeeded to collect the most homogeneous statistic data about the prices of flats are analysed below:

SE3 - (South East 7) Blackheath, Blackheath Park, Kidbroke;

SE7 - Charlton;

SE8 - Depford, St. John's; 
SE10 - Greenwich, Rangers House;

SE12 -Grove Park, Lee, Lee Green;

SE13 - Lewisham, Hither Green, Ladywell.

The 2001 year data shows that 214403 people lived in Greenwich and 248922 Lewisham [10]. The Royal Statistics Society even provides the indicator of non-white residents. They make up $22,89 \%$ of the population in Greenwich and 34,08 \% in Lewisham. This data shows the multinational aspect on these areas and also the whole London and the racial distribution in selected living areas (see Table 1).

Greenwich is among the greenest areas of London; the size of its parks considerably softens the effect of jams and makes the area attractive to those who search for a quiet oasis near London City and Canary Wharf where many high income residents work. The unemployment level is low here, as in England in general. Quite a number of people go to work by public transport (usually underground), especially to the centre. Car parking is even available near some of underground stations for those who came from more distant areas of London. $50 \%$ of dwellings are occupied by their owners, a number are rented; however, over one quarter of them is rented by munici- palities, thus the state sector has a significant share in the real estate market.

Average household is slightly more than two persons in these territories, thus the demand for especially large dwellings is limited despite the fact that more spacious dwellings are especially appreciated. Average age of residents in the areas is 35 , thus it may be assumed that the analysed areas are not "old" from the perspective of the age of residents. On the other hand, the majority of residents are immigrants who usually rent the dwellings.

Flats and semi-detached houses are the dominant types of dwellings in these areas and this trend considerably differs from the domination of individual dwellings in the UK.

The price for one square metre of the analysed flats is influenced by quantitative (total area, storey, etc.) and qualitative (flat condition, parking, general communications, noise level, additional spaces, etc.) factors.

Flat area is measured by feet in the UK, the data on the total area is usually not provided (it is usually limited to the measurement of rooms, corridors, sanitary units, etc.).

The storey in which the flat is situated must be mentioned because flats which occupy two storeys are marked with the intermediate

Table 1. Statistical data of Greenwich and Lewisham areas

\begin{tabular}{lll}
\hline Indicator & Greenwich & Lewisham \\
\hline Population & 214403 & 248922 \\
Population density, (people/1ha) & 45.29 & 70.81 \\
Change of population in 1991-2001, (\%) & +1.68 & +3.62 \\
Not white people, (\%) & 22.89 & 34.08 \\
Born abroad, (\%) & 18.04 & 23.91 \\
Unemployed (age group from 16 to 74), (\%) & 4.41 & 4.62 \\
Commuters (public transport), (\%) & 19.37 & 23.66 \\
Dwellings occupied by owners, (\%) & 48.95 & 50.12 \\
Rented from municipalities, (\%) & 29.2 & 26.6 \\
Rented via a registered agent or an agency, (\%) & 10.2 & 9.0 \\
Private rent, (\%) & 11.6 & 14.3 \\
Average household size & 2.3 & 2.3 \\
Households from one person, (\%) & 36.64 & 34.83 \\
Average number of rooms per household & 4.7 & 4.5 \\
Average age of population & 35.8 & 34.7 \\
\hline
\end{tabular}


number, i.e. 2.5 if the flat occupies 2 and 3 storeys.

Qualitative factors may be evaluated by points according to the available data.

Condition of a flat: 1-suitable for use (operating sanitary units and other internal equipment; unworn floor covering; the building, its roof and windows do not need serious repair works); 2- minor repair works are done in the flat or the flat is in a very good conditions (painted recently; floor covering, tiles, kitchen equipment replaced; etc.); 3- major repair works were done; sanitary units, windows, doors replaced; roof and external walls repaired; etc. within a year before the sales; 4 - a new construction flat.

Parking: 1- none; 2- parking place in the street; 3 - a private drive-in; 4- a garage; 5 - a garage and a private drive-in or two places with a private drive-ins'.

Additional spaces: 1- none; 2- a balcony; 3- a large balcony, a terrace, a small cobbled yard; 4- a common garden; 5- a private garden.

General communications - factor evaluated by measurement of two components (distance to a motorway and distance to an underground station).

Distance to a motorway: $1-4 \mathrm{~km}$ and more; 2- 3-4 km; 3- 2-3 km; 4- 1-2 km; 5- up to $1 \mathrm{~km}$.

Distance to an underground station: 1 - inconvenient access to a station; $2-1-2 \mathrm{~km}$ to a small station; 3- 1-2 $\mathrm{km}$ to a large station; 4less than $1 \mathrm{~km}$ to a large station or $500 \mathrm{~m}$ to a small; 5- less than $500 \mathrm{~m}$ to a station.

The calculations by STATISTICA provided average prices for one square meter of flats; their average prices and standard deviations (see Table 2). The data on prices of flats of January-February 2005 was also taken for comparison from the website of the official register bureau of the UK www.landreg.gov.uk.

The obtained average sales prices of twobedroom flats differ from the official only slightly and retain the same tendencies dependant on the locality. Flats are the most expensive in Blackheath (SE3) and the cheapest in Charlton (SE7). These tendencies are determined not only by advantages or disadvantages of the territories but also by other above-mentioned factors: their influence may be evaluated by applying mathematical-statistical methods of correlative-regressive analysis.

Regressive analysis allows defining relations between two or more interdependent factors so that the value of one factor may be defined with a certain probability when the value of another factor is known [2]. In other words, the regressive analysis is a method for finding a function where the squares of lengths of statistical data are minimal from the function to the whole selected sample. The regression straight may be determined according to two variables: the position (a) and rise (b). It is mathematically expressed by a common equation:

$$
y=a+b x,
$$

here: $a$ - intersection of the straight with the axis y; $b$ - rise ratio.

Using the application STATISTICA the intensity of the effect of various factors that in-

Table 2. Price trends of two-bedroom flats in the analysed London areas

\begin{tabular}{lllll}
\hline Area & $\begin{array}{l}\text { Average sales } \\
\text { price, } €\end{array}$ & $\begin{array}{l}\text { Average price } \\
\text { per } 1 \mathrm{~m}^{2}, €\end{array}$ & $\begin{array}{l}\text { Standard } \\
\text { deviation }\end{array}$ & $\begin{array}{l}\text { Average official sales } \\
\text { price, } €\end{array}$ \\
\hline SE3 & $348,812.91$ & 5,237 & 624.64 & $312,296.81$ \\
SE7 & $237,588.84$ & 4,156 & 475.54 & $208,002.62$ \\
SE8 & $268,173.91$ & 4,936 & 794.85 & $266,752.02$ \\
SE10 & $306,874.63$ & 4,960 & 685.95 & $390,700.28$ \\
SE12 & $266,292.27$ & 4,392 & 743.67 & $214,163.04$ \\
SE13 & $286,846.37$ & 4,782 & 883.35 & $254,410.28$ \\
\hline
\end{tabular}


fluence prices of two-bedroom flats in the South East London was determined (see Table 3) [38, 14].

Analysis revealed that in the area of Blackheath the price for one square meter of flat is strongly influenced by condition of the flat (the better the condition, the higher is the price) (see Figure 1).

It also must be admitted that available communications have significant influence to a square meter pricing of the flat. This factor is important in all areas of London; the flats located closest to underground stations are especially appreciated, because metro is the main means of transportation for reaching the city centre and it is used both by average and high income residents. Price of one square meter becomes lower as the size of flat increases. Availability of additional spaces, storey in which the flat is located and available parking notably influence the price of square metre of flat.

Strong relation between the condition of a flat and the price for one square metre is also noticed in SE8 (Depford, St. John's) area. Relation between the size of a flat and the price for one square metre is not very strong here; however, it is still positive. Thus it may be assumed that bigger and more spacious flats are also appreciated in this location. Stronger relation is seen when analysing availability of parking to the price of one square metre of two-bedroom flats. It may be noted that the flats with a private drive-in or a garage are appreciated most (see Figure 2). The problem of parking space is common to all densely populated London areas. Other analysed factors (communications, storey) have only an insig-

Table 3. Results of correlative-regressive analysis in South East London

\begin{tabular}{|c|c|c|c|c|c|c|c|c|c|}
\hline London areas & SE3 & & & SE8 & & & SE10 & & \\
\hline $\begin{array}{l}\text { Factors influencing the prices for } \\
\text { sq. meter }\end{array}$ & $\mathrm{r}$ & a & $\mathrm{b}$ & $\mathrm{r}$ & a & $\mathrm{b}$ & $\mathrm{r}$ & $\mathrm{a}$ & $\mathrm{b}$ \\
\hline Flat size $(\mathrm{X} 1)$ & -0.51 & 6351.4 & -14.42 & 0.21 & 4583.7 & 8.49 & -0.65 & 5667.8 & -11.77 \\
\hline Flat condition $(\mathrm{X} 2)$ & 0.91 & 4467.1 & 410.08 & 0.80 & 3830.9 & 579.16 & 0.23 & 4646.4 & 95.69 \\
\hline Communications (X3) & 0.75 & 4261.8 & 444.87 & 0.21 & 4622.7 & 171.78 & 0.37 & 4570.6 & 125.01 \\
\hline Parking (X4) & 0.30 & 5225.2 & 116.52 & 0.47 & 4030.8 & 404.73 & 0.19 & 4711.2 & 81.82 \\
\hline Additional space (X5) & 0.38 & 5059.6 & 150.98 & 0.20 & 4297.8 & 55.47 & 0.48 & 4417.7 & 180.00 \\
\hline Storey (X6) & 0.48 & 5223.0 & 148.00 & 0.35 & 4871.7 & 124.85 & 0.03 & 4882.5 & 6.40 \\
\hline
\end{tabular}

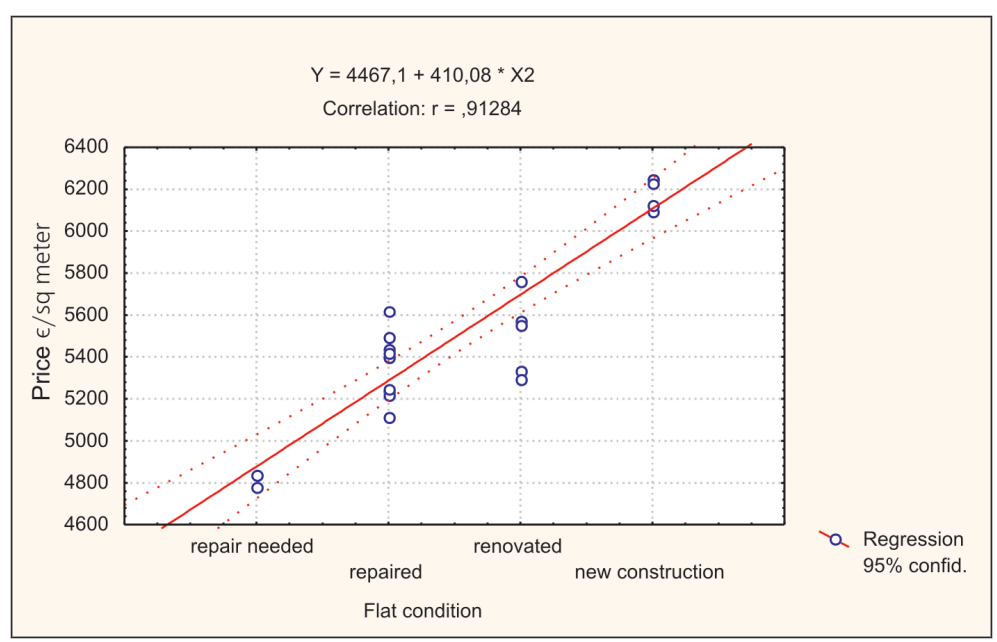

Figure 1. The influence of flat condition to the price of one square meter in SE3 area 


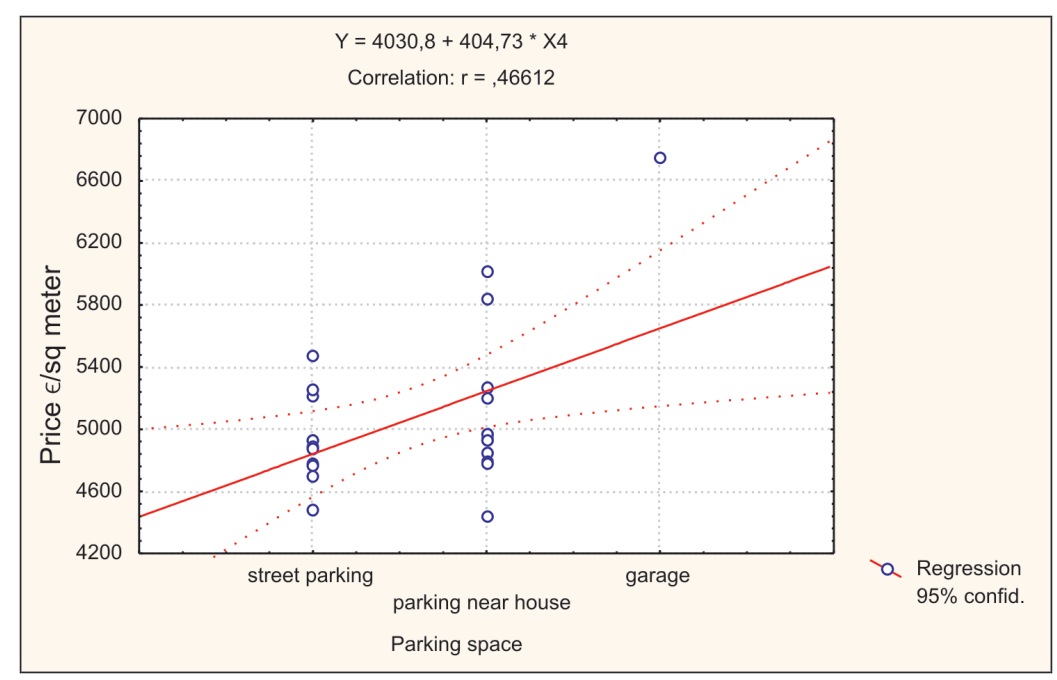

Figure 2. The influence of car parking to the price of one square meter in SE8 area

nificant influence to prices for one square metre, the obtained regression curves are almost horizontal, thus these dependencies are not analysed below.

Greenwich (SE10) is among the biggest tourist attraction centres in London; it is full of historical buildings, dwellings are most often rented. Relation between the flat size and price for one square metre is a bit weaker than usual; however, it is considerably negative and shows that smaller flats are more appreciated in this location (see Figure 3). Due to higher demand for dwellings, condition, transportation, available parking and storey have less influence to the price of one square metre of flat. However, stronger relation is obtained between price for one square metre and additional spaces. Flats having larger spaces, gardens, yards or terraces are appreciated more.

The relation between the size and price for one square metre is considerably negative in Lee Green, its correlation $(r=-0,51)$. It must be noted that price for one square metre strongly depends upon the condition of a flat $(r=0,98)$; the influence of available parking is also significant $(\mathrm{r}=0,54)$.

Strong relation between the condition of a flat and price for one square metre is noticed in Lewisham and its correlation $(r=0,81)$. Ad- vantages of more convenient parking are also appreciated in this area $(\mathrm{r}=0,88)$; most probably due to intensive traffic in the streets.

In order to determine whether the aboveanalysed factors have significant influence to prices of flats in general, multiply correlativeregressive analysis was carried out. It was determined that the results of the analysis meet the above-analysed results of the pair regressive-correlation analysis. In case of SE3 area, quite high coefficient of the multiply correlation is obtained $\left(\mathrm{R}^{2}=0,89\right)$; and it means that $89 \%$ of the price of a flat in the analysed location depends upon the above-analysed factors. The equation of the multiply regression again underlines the significant influence of condition of a flat to the price for one square metre:

$$
\begin{aligned}
& y=4384,182-2,591 X 1+322,702 X 2+96.682 X 3 \\
& +14,392 X 4+58,049 X 5+11,786 X 6 .
\end{aligned}
$$

Multiply analysis flats pricing in SE8 area revealed that the price of a flat depends upon the above-analysed factors by $67 \%\left(\mathrm{R}^{2}=0,67\right)$; the condition of a flat again has the biggest influence:

$$
\begin{aligned}
& y=2924,254+5,330 X 1+472,049 \times 2+50,154 X 3 \\
& +78,585 X 4+61,800 X 5+52,898 X 6
\end{aligned}
$$




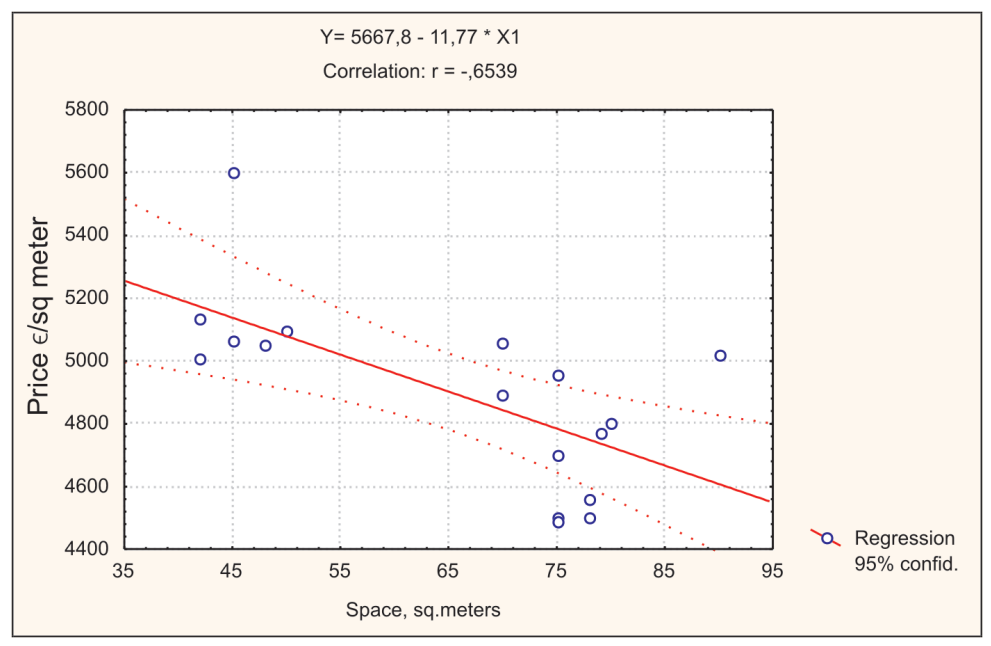

Figure 3. The influence of flat space to the price of one square meter in SE10 area

However, it should be noted that in order to evaluate more precisely influence of factors to the price of flats in this territory, a more detailed analysis is necessary with the evaluation of other unanalysed factors (e.g. infrastructure, pollution, noise level, neighbours, etc.).

The pricing of square metre of flat in SE10 area is most influenced by the size of a flat. While evaluating the influence of the aboveanalysed factors, it must be noted that the price of a flat considerably depends upon the analysed factors $\left(R^{2}=0,78\right)$. The following equation of multiply regression is obtained:

$$
\begin{aligned}
& y=5232,389-113,56 X 1+76,717 X 2+ \\
& 15,154 X 3+5,980 X 4+15,048 X 5-5,353 X 6 .
\end{aligned}
$$

When the required data is known, quite exact prices for two-bedroom flats may be determined in the areas by using these equations.

In conclusion, it may be claimed that condition and size of a flat are the main factors influencing prices of two-bedroom flats in the South East London. The significance of other factors most often depends upon a certain area. However, available transportation, parking or even racial distribution of neighbours should be considered while determination the value of flats.
As it was mentioned before, high dwelling prices are common in London; the prices have become stable or even have fallen due to growing loan interest rates in recent years [15]. The prices for flats in Vilnius are continuing to grow intensively. Despite the general tendencies in marked dynamics, it should be remembered that value of a certain flat is determined by various factors just like in London; it is reasonable to analyse the effect of the factors in more detail.

\section{PRICES OF THREE-ROOM FLATS IN VILNIUS AND THE DETERMINING FACTORS}

In recent years, the dwelling market in the city of Vilnius is developing intensively; threeroom flats are not an exception, although their prices grew slower than the prices for one- or two- room flats (see Figure 4) [1, 9, 12, 13, 17].

Currently, the prices of flats of average old construction located in prestigious areas of Naujamiestis and the Old Town reach $1496 € / \mathrm{m}^{2}$, about $1330 € / \mathrm{m}^{2}$ in Antakalnis and about $985 € / \mathrm{m}^{2}$ in Fabijoniškès, Pašilaičiai, Šeškinè and other residential areas.

When comparing prices for one square metre of three-room flats in Vilnius with the 


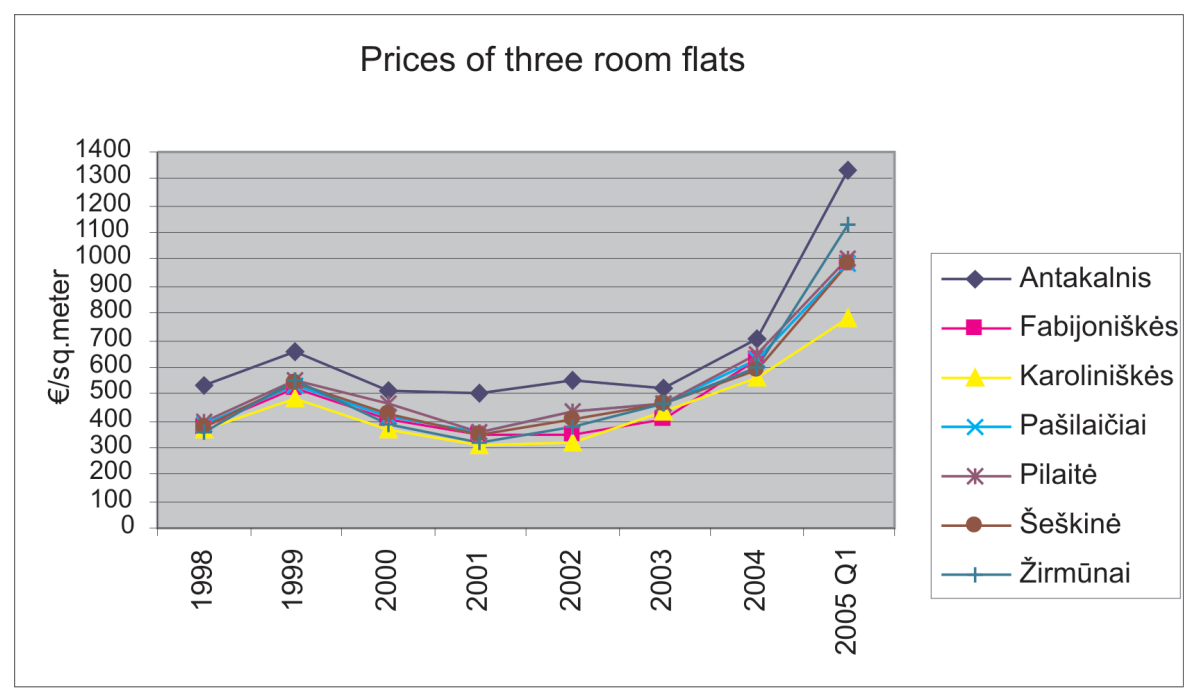

Figure 4. Price development of three-room flats in Vilnius

above-analysed prices in South East London, it may be noticed that they are 4-5 times lower than in London. These differences are determined not only by higher living standard in London but also by the layout of flats and life quality.

When analysing prices of flats in Vilnius, other factors related to characteristics of multistorey buildings must be analysed together with the above-mentioned factors. Thus factors already analysed with flats in London are selected for the further analysis, as well as additional factors of building age and construction type, which are topical both to the prices of flats in multi-storey buildings in Lithuanian and prices of flats in capitals of other countries in transition period dominated by apartment houses of mass construction (see Table 4).

Table 4. Factors influencing prices of flats in Vilnius

\begin{tabular}{|c|c|c|}
\hline Factor & Evaluation & Definition \\
\hline Storey in which the flat is located (X1) & Number & Storey \\
\hline Total area of the flat (X2) & $\mathrm{m}^{2}$ & \\
\hline \multirow[t]{3}{*}{ Building construction (X3) } & Points & 1-large-panel building \\
\hline & & 2-cast-in-place building \\
\hline & & 3- brick building \\
\hline \multirow[t]{5}{*}{ Age of building (X4) } & Groups & 1- constructed before 1924 \\
\hline & & 2- constructed in $1924-1948$ \\
\hline & & 3- constructed in $1948-1972$ \\
\hline & & 4- constructed in 1972-1996 \\
\hline & & 5- constructed after 1996 \\
\hline \multirow[t]{4}{*}{ Condition of flat (X5) } & Points & 1- abandoned \\
\hline & & 2- need repair \\
\hline & & 3- good condition \\
\hline & & 4- repaired, luxury \\
\hline \multirow[t]{4}{*}{ Communications with centre of the city (X6) } & Points & $1-30 \mathrm{~min}$ to the centre \\
\hline & & 2- $15-30 \mathrm{~min}$ to the centre \\
\hline & & $3-10-15 \mathrm{~min}$ to the centre \\
\hline & & 4- up to $10 \mathrm{~min}$ to the centre \\
\hline
\end{tabular}


Areas of Naujamiestis, the Old Town, Antakalnis, Fabijoniškès, Justiniškès and Šeškinè are selected for the analysis. The results of pair correlative-regressive analysis are provided in Table 5.

Prices of three-room flats in the prestigious areas of the Old Town and Naujamiestis reach $1496 € / \mathrm{m}^{2}$. Regressive-correlative analysis revealed that the biggest influence to the price for one square metre has the condition of a flat (see Figure 5) and the construction year. Flats in buildings of newer construction or flats of better condition are appreciated more.

Brick buildings dominate in these areas; therefore, the construction type does not influence the price significantly in this case. The communications in most cases are very convenient; therefore, the coefficient of correlative dependency is low. The storey of a flat does not have a significant influence on the price as well. Besides, it should be noted that lower apartment buildings usually dominate in these areas. The lowest influence to the price of one square metre of three-room flats has the size of a flat, because both smaller and larger threeroom flats are demanded in these prestigious areas.

Having completed the multiply regressivecorrelative analysis it appeared that the analysed factors have a significant influence on the prices for three-room flats $\left(R^{2}=0,71\right)$. The equation of multiply regression again underlines the importance of the influence of condition of flat and construction year on the price for one square metre of three-room flats:

$$
\begin{aligned}
& y=472,0314+0,6367 X 1+208,8504 X 2+14,2831 X 3 \\
& +123,1206 X 4+3,9305 X 5+4,17 X 6
\end{aligned}
$$

\begin{tabular}{|c|c|c|c|c|c|c|c|c|c|}
\hline Areas in Vilnius & \multicolumn{3}{|c|}{ The Old Town, Naujamiestis } & \multicolumn{3}{|c|}{ Antakalnis } & \multicolumn{3}{|c|}{ Fabijoniškès, Justiniškès, Šeškinè } \\
\hline $\begin{array}{l}\text { Factors influencing the } \\
\text { prices for sq. meter }\end{array}$ & $\mathrm{r}$ & $\mathrm{a}$ & $\mathrm{b}$ & $\mathrm{r}$ & $\mathrm{a}$ & $\mathrm{b}$ & $\mathrm{r}$ & $\mathrm{a}$ & $\mathrm{b}$ \\
\hline Flat size $(\mathrm{X} 1)$ & 0.08 & 1359.6 & 1.66 & -0.02 & 1354.7 & -0.32 & -0.20 & 1122.9 & -1.87 \\
\hline Flat condition (X2) & 0.79 & 749.7 & 286.1 & 0.67 & 836.7 & 189.32 & 0.66 & 30.87 & 169.9 \\
\hline Construction type (X3) & 0.18 & 1133.7 & 126.02 & 0.41 & 808.19 & 189.25 & 0.38 & 64.33 & 77.16 \\
\hline Construction year (X4) & 0.68 & 789.1 & 239.71 & 0.49 & 285.65 & 255.30 & 0.53 & 76.02 & 133.56 \\
\hline Communications (X5) & 0.11 & 1248.7 & 70.11 & 0.45 & 403.48 & 332.36 & 0.11 & 911.26 & 43.92 \\
\hline Storey (X6) & 0.24 & 1373.8 & 40.25 & 0.24 & 1453.9 & 52.38 & 0.12 & 1019.00 & -7.29 \\
\hline
\end{tabular}

Table 5. Results of correlative-regressive analysis of flats in Vilnius

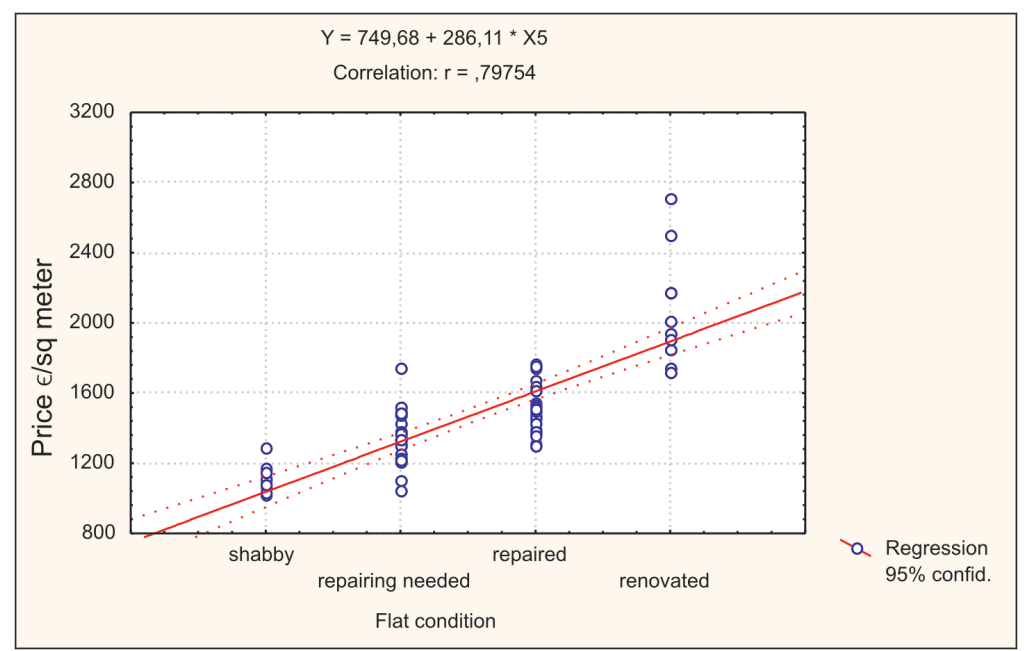

Figure 5. The influence of flat conditions to the price of one square meter in the Old Town and Naujamiestis 
Similar tendencies are noticed in other prestigious area of Vilnius, namely Antakalnis. Condition of a flat has significant influence on the price for three-room flats. Beside the construction year, the influence of another factor, namely the construction type, becomes obvious (see Figure 6). Antakalnis is dominated not only by brick but also by large-panel houses; therefore, it is clear that newer threeroom flats in brick buildings are priced higher.

Available communications to the centre has significant influence to the price of a flat. The influence of total area to the price of one square metre is insignificant as in the above-analysed areas.

The correlation coefficient of price dependence on the storey is slightly higher but positive. Most probably, flats in higher storeys are sometimes more priced for panoramic views.

On the basis of the results of the multiply regressive-correlative analysis, it may be claimed that the analysed factors have significant influence on the price for one square metre of three-room flats in the area $\left(\mathrm{R}^{2}=\right.$ $0,82)$. The regressive equation underlines the influence of the factor of condition:

$$
\begin{aligned}
& y=377,230-0,776 X 1+147,330 X 2+ \\
& 6,086 X 3+78,388 X 4+2,459 X 5+12,24 X 6 .
\end{aligned}
$$

Analysis of pricing of three-room flats in residential areas of Fabijoniškès, Justiniškès and Šeškine in Vilnius shows that the influence of various factors is different. First, the influence of size upon the price is higher than in the above-analysed areas and has a negative effect (see Figure 7). The bigger the size, the cheaper the flat may be. Such tendency may be determined by relatively lower income of residents in the areas as well as by energy savings.

The influence of condition of a flat is also the highest in this case; however, it is slightly lower than in prestigious areas of Vilnius. The influence of construction type is lower than in Antakalnis, because the areas are dominated by large-panel old construction buildings. Construction year has a more significant influence to the price of a flat; a tendency is clear that newer construction flats are more expensive. The indicator of communications has considerably lower influence to the price than in Antakalnis. Such tendency may be partially determined by the fact that the analysed areas are located near each other and the distance and communications to the centre is relatively inconvenient in all cases. The storey in which the flat is located has only a slight in-

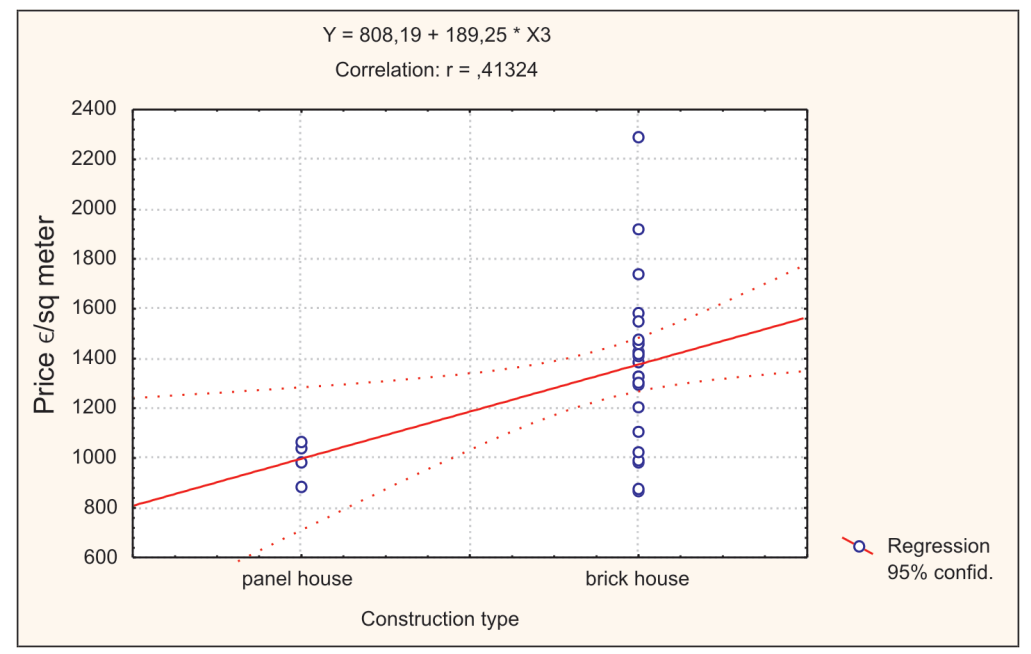

Figure 6. The influence of the construction type to the price of one square meter in Antakalnis 


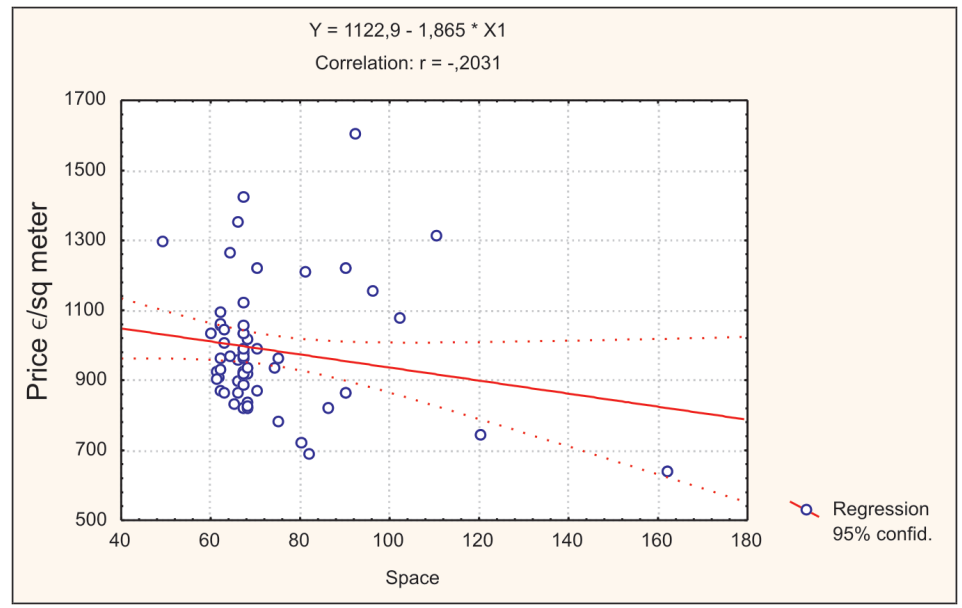

Figure 7. The influence of size to the price of one square meter in residential areas of Vilnius

fluence to the prices of flats; however, the obtained negative correlation coefficient shows that flats located in lower storeys are also demanded in these areas (especially ground floors, which are used for shops, internet cafés, dentist services, etc.).

The results of the multiply correlative-regressive analysis show that above mentioned factors have significant influence to the prices of three-room flats $\left(R^{2}=0,74\right)$. The coefficients of the multiply regression equation underline the influence of the condition of a flat and construction year to the price of three-room flats:

$$
\begin{aligned}
& y=402,9656-3,63 X 1+195,5039 X 2+57,3370 \times 3+ \\
& 100,933 X 4+4,43 X 5-2,0132 X 6 .
\end{aligned}
$$

It can be summarized that the prices of three-room flats in Vilnius mostly are determined by location. The flats located in prestigious areas of the Old Town, Naujamiestis and Antakalnis have highest prices. The most important factor determining the price for one square metre in these areas is the condition of flats. It also should be noted that the size of a flat has only insignificant influence on the price of one square metre and it may be partially related to the recent tendency that bigger flats are also demanded in the central parts of the city. The size is more significant to the price in the residential areas of Fabijoniškès, Justiniškès and Šeškine where residents with relatively lower income live.

The influence of construction type to the price for one square metre of a tree-room flat is significant in these areas where large-panel mass construction buildings dominate. The prices for flats in brick buildings significantly differ and are higher than the prices in largepanel buildings. Besides, flats in new construction houses are more expensive in all analysed areas.

The storey in which the flat is located does not have a significant influence to the price for one square metre. Only a tendency is noticed that flats in higher storeys are more demanded in Antakalnis due to panoramic views; on the other hand, flats in the ground floor suitable for commercial activities usually are more expensive in residential areas.

Comparing the factors determining the prices of three-room flats in Vilnius and the factors determining prices of flats in London, it may be noted that in both cases the condition of flats is the essential factor. The factor of size both in the central areas of Vilnius and in territories of South East London located near the centre does not have a significant influence to the price for one square metre. However, the influence of this factor is more im- 
portant and negative in residential areas, i.e. smaller flats are appreciated more.

Since London is a large metropolitan city, communication with centre is an important factor as well as available parking due to a frequent lack of area around a house. Communications with centre in the analysed areas of Vilnius compared to those of London are more convenient. Therefore, communications do not have a significant influence to the price of square meter of flat in Vilnius. The influence of available parking in Vilnius was not analysed, because in many cases a parking lot is available at each apartment house and closed yards in central areas.

Availability of additional spaces, which has influence on prices of two-bedroom flats in South East London, was not analysed in Vilnius, because the old construction flats in Vilnius are standard with no additional spaces planned.

When analysing prices of flats in Vilnius, construction year and construction type were included as additional factors; these factors are not important in London, because in London there are no areas with large-panel buildings and the construction year most often (contrary to Vilnius) has a positive influence on the price of one square metre.

\section{CONCLUSIONS}

The dependence of prices for one square metre for two-bedroom flats in the South East London (SE3, SE7, SE8, SE10, SE12 and SE13) was analysed using mathematical-statistical methods. The following factors were analysed: condition of flats, size $\left(\mathrm{m}^{2}\right)$, available parking, and distance to an underground station and motorway, general communications, additional spaces and a storey. Having calculated arithmetic averages of sales prices in each area and having compared them with the official statistics, it may be stated that similar tendencies prevail: the flats are the most expensive in Greenwich, Blackheath and the cheapest in Charlton. The prices are closest to the arithmetic average in Charlton (standard deviation $\pm 475.57 € / \mathrm{m}^{2}$ ), and the most unreliable prices are in Lewisham (standard deviation \pm 883.35 $\left.€ / \mathrm{m}^{2}\right)$.

In Blackheath and its suburbs, the price for one square meter mostly depends on the condition of a flat and the communications; in Charlton on the size; in Depford on the condition of a flat and available parking; in Greenwich on the size; in Lee partially on the parking and the size; in Lewisham on the condition and available parking.

For the comparison of factors influencing the prices of one square metre, the prices of similar (according to the size) three-room flats and the determining factors in Vilnius were analysed. It was determined that flats are the most expensive in the prestigious areas of Vilnius: the Old Town and Naujamiestis where the average price is $1496 € / \mathrm{m}^{2}$ and Antakalnis (about $1330 € / \mathrm{m}^{2}$ ). The prices for one square metre in residential areas of Fabijoniškès, Pašilaičiai and Šeškinè are lower and make up about $985 € / \mathrm{m}^{2}$. Compared to the prices for one square metre in London, the prices in Vilnius are 4-5 times lower. These tendencies are determined by various factors, and the condition of flats is the most important (like in London). Due to the small size of Vilnius compared to that of London, communications have only a small influence on the price of one square metre; the problem of parking is also not urgent in Vilnius. However, while evaluating the prices of flats in Vilnius, the factors of construction year and construction type must be considered, especially in Antakalnis, Fabijoniškès, Pašilaičiai and Šeškinè, which are dominated by large-panel buildings. In Vilnius, the influence of size is significant in residential areas (just like in London) where the price for one square metre is higher in smaller flats.

\section{REFERENCES}

[1] ARUODAS. http://www.aruodas.lt [accessed 200502 10]

[2] Bartosevičienè, V. Economic statistics. Kaunas: Technologija, 2004. 108 p. (in Lithuanian) 
[3] BERKELEY HOMES. http:// www.berkeleyhomes.co.uk [accessed 200502 22]

[4] BIG NAMES: DOMAIN NAMES, WEB SITE HOSTING AND BUILDING. http:// www.buyprivately.co.uk [accessed 20050201$]$

[5] FIND A PROPERTY. http:// www.findaproperty.co.uk [accessed 200502 22]

[6] GREENWICH COUNCIL. http:// www.greenwich.gov.uk [accessed 200502 04]

[7] HOMECO INTERNET PROPERTY Ltd. http:/ /www.home.co.uk [accessed 200502 26]

[8] HOMES \& PROPERTY. http:// www.homesandproperty.co.uk [accessed 2005 $0201]$

[9] IN-REAL. http://www.in-real.lt [accessed 2005 $0212]$

[10] LEWISHAM COUNCIL. http:// www.lewisham.gov.uk [accessed 20050204 ]

[11] MULTIMAP. http://www.multimap.com [accessed 200502 10]

[12] OBER-HAUS UAB. http://www.ober-haus.lt [accessed 20050211$]$
[13] S. Raslanas, Research of market value of multistorey housing in Vilnius city, Technological and Economic Development of Economy, 10(4), 2004, p. 167-174 (in Lithuanian).

[14] S. Raslanas and T. Šteinbergas, Peculiarities of Lithuanian favourite south-east London flats prices, Real estate, No. 11, 2005, p. 42-44 (in Lithuanian).

[15] RICS EUROPEAN HOUSING REVIEW, 2005. http://www.rics.org [accessed 200501 16]

[16] H. Sieg, V. K. Smith, H. S. Banzhaf and R. Wash, Interjurisdictional housing prices in locational equilibrium, Journal of Urban Economics, 52(1), July 2002, p. 131-153.

[17] E. K. Zavadskas, A. Kaklauskas and S. Raslanas, Evaluation of investments into housing renovation, International Journal of Strategic Property Management, 8(3), 2004, p. 177-190.

[18] I. D. Wilson, S. D. Paris, J. A. Ware and D. H. Jenkins, Residential property price time series forecasting with neural networks, Knowledge Based Systems, 15, 2002, p. 335-341.

\section{SANTRAUKA}

\section{PIETRYČIŲ LONDONO IR VILNIAUS BUTŲ KAINŲ TYRIMAI}

\section{Saulius RASLANAS, Laura TUPĖNAITĖ, Tadas ŠTEINBERGAS}

Taikant matematinius statistinius metodus buvo išanalizuotos butų su dviem miegamaisiais kainos pietryčių Londone bei panašaus ploto trijų kambarių butų kainos Vilniuje. Analizès metu nustatyta, jog vidutinès trijų kambarių butų kainos Vilniuje yra 4-5 kartus mažesnès nei butų su dviem miegamaisiais Londone. Buvo išanalizuoti ir palyginti butų kainoms įtaką turintys veiksniai: buto plotas, buto būklè, susisiekimas, vieta automobiliui, papildomos erdvès, aukštas, kuriame yra butas, ir kt. Nustatyta, jog Vilniaus trijų kambarių butų kainas lemia kai kurie papildomi veiksniai nei Londone. Daugiau dėmesio reikia skirti daugiaaukščių pastatų amžiui ir konstrukcijos tipui. Šie veiksniai yra svarbūs miegamuosiuose Vilniaus rajonuose, kur vyrauja stambiaplokščiai pastatai: Antakalnyje, Fabijoniškẻse, Pašilaičiuose, Šeškineje ir pan. Kiti butų kainoms įtaką darantys veiksniai yra panašūs į Londono: buto būkle dažniausia yra svarbiausias veiksnys, darantis įtaką trijų kambarių butų kainoms Vilniuje. Kadangi Vilnius yra daug mažesnis už Londoną, susisiekimas ir galimybė pasistatyti automobilį neturi didelès įtakos trijų kambarių butų kainoms Vilniuje. Panašiai kaip ir Londone, buto plotas turi daugiau ịtakos Vilniaus miegamųjų rajonų butų kainoms nei centrinėse miesto dalyse bei prestižiniuose rajonuose esančių butų kainoms. 